schermen' afspeelt. De geïnteresseerde patiënt/cliënt kan daarbij de gesproken informatie via een koptelefoon beluisteren, zodat de apotheker en diens assistenten niet de gehele dag worden lastig gevallen met een eindeloos herhaalde luidsprekertekst. De Commissie voor Collectieve Voorlichting bezint zich thans, naar aanleiding van vragen van collegae hieromtrent, op het - bij wijze van proef realiseren van een dergelijk project.

Lezingen, geillustreerd met dia's, blijken het nog steeds goed te doen. Dit was ook de KNMP al duidelijk, afgaande op de vele aanvragen om de beide bestaande diaseries te lenen.

Video-apparatuur wordt steeds hanteerbaarder, eenvoudiger te bedienen en goedkoper. Het stadium lijkt nu te zijn aangebroken dat apothekers die samen met hun assistenten eens een 'rollenspel' willen beginnen, video kunnen hanteren als leerzaam hulpmiddel en niet langer als 'kostbaar speelgoed'. Ook leent video zich uitstekend voor instructies van handelingen die in woorden moeilijk kunnen worden uitgelegd. Het spreekwoord 'een beeld zegt meer dan honderd woorden' zou bij video kunnen worden vervangen door 'bewegende beelden met geluid zeggen meer dan duizend woorden'.

Mediavisie 1979 kan men zonder overdrijving als een zeer geslaagde manifestatie omschrijven. Elke farmaceut die de tentoonstelling heeft bezocht, zal ongetwijfeld terugkomen bij een volgende gelegenheid.

M. I. W. M. HEIJTVELDT

\title{
PERSONALIA
}

\section{APOTHEKEN: NIEUWVESTIGINGEN}

Apotheek Elckerlyc, Laanweg 45, I87I BK Schoorl, Drs. D. IJ. BoumA.

Apotheek Hilvarenbeek, Paardenstraat I9, 508I cG Hilvarenbeek, Mevr. Drs. TH. c. DE KLAVERv. DOOREMALEN.

Apotheek Adelheid, Kerksingel 25, $2560 \mathrm{cc}$ Berkel en Rodenrijs, Mevr. Drs. A. A. M. vaN RoosTJACOBS.

\section{APOTHEKEN： MUTATIES GEVESTIGDE APOTHEKERS}

De Batouwe Apotheek, Rijksweg Noord 4, 666I Kg Elst, Drs. P. GRIFFIOEN.

Apotheek van der Laan, Bloemfonteinstraat 97, 3072 HE Rotterdam, Mevr. Drs. B. HAdILAKsono. Apotheek Heinsius, Molenstraat 98, 65I I HJ Nijmegen, Mevr. Drs. G. M. SAUER.

Apotheek Giltay, Nassaukade 8, I052 CE Amsterdam, Mevr. Drs. H. A. M. VAN DER veldE.

\section{APOTHEKEN: MUTATIES TWEEDE APOTHEKERS}

Apotheek Overtoomse Veld, Derkinderenstraat 68, I062 вJ Amsterdam, Mevr. Drs. M. BRUIJN. De Batouwe Apotheek, Rijksweg Noord 4, 666I kg Elst, Prof. Dr. J. M. VAN Rossum.

\section{OVERLEDEN}

Op 30 april 1979 is te Rotterdam op de leeftijd van 78 jaar overleden de heer TH. EXLER, apotheker.

JUBILEA

40 Jaar apotheker, 9 juni I979: de heer F. J. E.
H. HAAN te Roermond; Io juni 1979 de heer Ir. T. HOEKSTRA te Enkhuizen.

DOCTORAALEXAMEN

Amsterdam, 2 mei I979: de heer W. RAUWERDINK. 